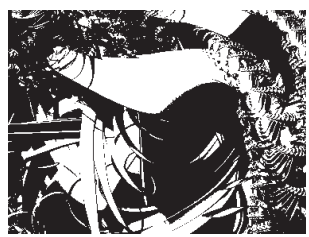

\title{
OBRAZOVANJE I FERTILITET ZAPOSLENIH ŽENA U HRVATSKOJ
}

Ivan ČIPIN

Ekonomski fakultet, Zagreb

UDK: $331.101 .232-055.2(497.5): 37$

$331.101 .25-055.2(497.5)$

$314.17(497.5): 331$

$314.145(497.5): 331$

Izvorni znanstveni rad

Primljeno: 20. 7. 2010.

Ovaj rad ispituje u kojoj je mjeri razina obrazovanja žena povezana s njihovim demografskim ponašanjem, prije svega s dobi rađanja prvoga djeteta i brojem djece. Svrha je rada ispitati postoji li i koliko je značajna razlika u dobi rađanja prvoga djeteta između žena s različitim stupnjevima obrazovanja. Isto tako, ispituje se koliko povećani obrazovni status dieluje na kvantum fertiliteta. $U$ radu su multinomna logistička regresija i druge statističke tehnike primijenjene na proporcionalni kvotni uzorak od 1309 zaposlenih žena od 20 do 39 godina iz anketnog istraživanja provedenog 2007. godine u Hrvatskoj. Rezultati su pokazali kako postoje razlike u fertilitetu među ženama različite razine obrazovanja te da obrazovni status ima važnu ulogu u određivanju vremena fertiliteta. Prilikom oblikovanja mjera pronatalitetnih politika trebalo bi voditi računa o tome da najveću razliku između željenoga i ostvarenoga broja djece nalazimo kod visokoobrazovanih žena.

Ključne riječi: fertilitet, dob pri prvom porodu, razina obrazovanja žena, zaposlene žene

Ivan Čipin, Ekonomski fakultet Sveučilišta u Zagrebu, Trg J. F. Kennedyja 6, 10000 Zagreb, Hrvatska.

E-mail: icipin@efzg.hr

Fertilitet u Hrvatskoj, mjeren totalnom stopom fertiliteta (TFR), nizak je još od kraja 1960-ih. Štoviše, prema nekim drugim pokazateljima reprodukcije, nizak fertilitet u Hrvatskoj neprekidno traje još od kraja 1950-ih (Wertheimer-Baletić, 1971.). 
DRUŠ. ISTRAŽ. ZAGREB GOD. 20 (2011) BR. $1(111)$

STR. $25-46$

ČIPIN, I.:

OBRAZOVANJE...
No tek od početka 1990-ih, zbog pada TFR-a na vrlo nisku razinu i pod značajnim utjecajem negativnoga demografskog momentuma, počeo je proces prirodne depopulacije, koji traje do danas. Cinitelji snižene reprodukcije u drugoj polovici 20. stoljeća u Hrvatskoj su brojni (Wertheimer-Baletić, 2003.), a empirijska demografska istraživanja pokazala su da su u 1990-ima ekonomski činitelji bili posebno naglašeni (Akrap, 2003.). Posljednja su dva desetljeća, iz perspektive pada fertiliteta na vrlo nisku razinu, posebno zanimljiva. Naime, padom autoritarnih režima i tranzicijom u kapitalističko političko i ekonomsko okruženje potkraj 1980-ih i na početku 1990-ih doslovno su se srušili dotadašnji društveni uvjeti koji su vrijedili u bivšim socijalističkim državama srednje i istočne Europe, uključujući i Hrvatsku. Ovisno o specifičnostima pojedine zemlje, u većoj ili manjoj mjeri, to je utjecalo na demografske indikatore, osobito na one vezane uz fertilitet. U sklopu te transformacije jedan od važnijih činitelja pada fertiliteta na vrlo nisku razinu jest sve veće ulaganje u visoko obrazovanje, posebno ženskoga stanovništva.

U razdoblju ekonomske transformacije i procesa globalizacije postoji potreba za stalnim profesionalnim usavršavanjem i ulaganjem u ljudski kapital. Danas, mlade žene provode više vremena u obrazovnom sustavu nego prijašnje generacije i sposobnije su kapitalizirati više obrazovanje (Martin-Garcia, 2008.). Pojedini demografi (Lesthaeghe, 2001.; Sobotka, 2004.) posebno naglašavaju sve veću obrazovanost žena i ekonomsku autonomiju kao glavne činitelje koji su oblikovali nove oblike formiranja obitelji i odgodu rađanja, posebno prvoga djeteta. Kada odgađa rađanje prvoga djeteta, ženi se, kao rezultat produženoga školovanja, povećavaju šanse za dobivanje bolje plaćenoga posla, akumulacije poslovnih vještina i iskustva. No visoka osobna očekivanja mladih žena u smislu obrazovanja, posla i sl. nisu u skladu s okruženjem i institucijama koje ženu ne podupiru (McDonald, 2000.). Suočena s dvostrukom ulogom zaposlene žene i majke, u neodgovarajućim i nepoticajnim uvjetima, nerijetko mora žrtvovati jednu od tih uloga. Najčešći je rezultat odgađanje rađanja za kasnije godine ili, u najgorem slučaju, odustajanje od djece.

\section{Tercijarno obrazovanje i fertilitet}

U zadnjih nekoliko desetljeća došlo je do promjene obrazovne strukture stanovništva u odnosu na onu u 1960-ima (Pokos, 2005.), posljednjem desetljeću kada je TFR u Hrvatskoj bio iznad zamjenske razine. Sve veći udio žena u tercijarnom obrazovanju izravno dovodi do odgode rađanja prvoga djeteta. Na nju utječu, među ostalim, produženo školovanje te očekivani povrat od ulaganja u ljudski kapital (Billari i Philipov, 2004.). Sve veći obuhvat mladih školovanjem, posebice mladih žena, sve 
DRUŠ. ISTRAŽ. ZAGREB GOD. 20 (2011), BR. 1 (111)

STR. 25-46

ČIPIN, I.: OBRAZOVANJE... duže školovanje na visokoškolskim ustanovama utjecalo je na odgodu rađanja, jer su se godine školovanja produžile u prvo desetljeće reproduktivnog razdoblja $(15$ - 24) i tako ga neizravno skratile. Nedvojbeno, prilično je teško kombinirati redovito školovanje i roditeljstvo (Blossfeld i Huinink, 1991.), posebice ako ne postoji institucionalna podrška koja će mladim ženama omogućiti lakše usklađivanje tih dviju uloga.

Bolje obrazovana žena ima veće oportunitetne troškove imanja djece stoga i odgađa rađanje dok na poslu ne stekne određeni stupanj karijere. Istraživanja pokazuju da obrazovanje snažno utječe na odgodu rađanja prvoga djeteta za kasnije godine (Liefbroer i Corijn, 1999.; Baizan i sur., 2003.; Lappegard i Rønsen, 2005.). Buber je (2001.) na primjeru Austrije našao da visokoobrazovane žene odgađaju rađanja i u prvim godinama nakon završetka školovanja, jer su im oportunitetni troškovi imanja djece tada najviši. U mnogim je europskim zemljama ekspanzija tercijarnog obrazovanja ključni činitelj koji vodi k odgodi formiranja obitelji (Hoem, 1986.; Billari i Philipov, 2003.; Kantorová, 2004.; Billari i Philipov, 2004.). Ovaj je učinak ojačao produljenjem razdoblja između završetka obrazovanja i roditeljstva, osobito za žene s višim stupnjem obrazovanja, a posebno u bivšim socijalističkim zemljama (Kantorová, 2004.; Huinink i Kreyenfeld, 2004.; Róbert i Bukodi, 2005.). Pozicioniranje na poslu i njegova stabilnost te ostvarenje relativno zadovoljavajućega životnog standarda sve je većem broju žena važan preduvjet prije nego što se odluče na rađanje.

U europskim državama žene s tercijarnom razinom obrazovanja znatno su više uključene u tržište rada i imaju više stope zaposlenosti od žena s nižim stupnjevima obrazovanja, bez obzira na broj djece (vidjeti Tablicu 1). Ženama s nižim stupnjem obrazovanja općenito je teže naći posao, a još teži im može biti povratak na posao nakon rodiljnoga dopusta. Nasuprot tomu, žene s tercijarnim obrazovanjem uglavnom ostaju na tržištu rada i nakon rođenja djeteta, tj. nakon završetka rodiljnoga dopusta. U većini zemalja stope zaposlenosti visokoobrazovanih žena koje nemaju djecu značajno se ne razlikuju od onih s jednim djetetom ili dvoje djece. Tek eventualno u pojedinim zemljama stopa zaposlenosti padne za više od 10 postotnih bodova kod žena s troje ili više djece. U nekima se stopa zaposlenosti žena s jednim djetetom ili dvoje djece čak i poveća u odnosu na žene bez djece. Takva je situacija i u Hrvatskoj, gdje žene s dvoje djece, a koje imaju tercijarno obrazovanje, imaju veću stopu zaposlenosti nego žene s jednim djetetom i one bez djece. $S$ druge strane, kod žena sa srednjom razinom obrazovanja razlike između žena bez djece i onih s djecom nešto su zamjetnije nego kod žena s tercijarnim obrazovanjem. Vjerojatno tome pridonose priroda po- 
DRUŠ. ISTRAŽ. ZAGREB GOD. 20 (2011), BR. 1 (111)

STR. 25-46

ČIPIN, I.:

OBRAZOVANJE..

(1) TABLICA 1

Stopa zaposlenosti žena od 25 do 49 godina prema razini obrazovanja i broju djece $u$ odabranim europskim zemljama, 2006.

\begin{tabular}{|c|c|c|c|c|c|c|c|c|c|c|c|c|}
\hline \multirow[b]{2}{*}{ Zemlja } & \multicolumn{4}{|c|}{$\begin{array}{l}\text { Primarno } \\
\text { Broj djece }\end{array}$} & \multicolumn{4}{|c|}{$\begin{array}{l}\text { Sekundarno } \\
\text { Broj djece }\end{array}$} & \multicolumn{4}{|c|}{$\begin{array}{l}\text { Tercijarno } \\
\text { Broj djece }\end{array}$} \\
\hline & 0 & 1 & 2 & $3+$ & 0 & 1 & 2 & $3+$ & 0 & 1 & 2 & $3+$ \\
\hline Belgija & 53,3 & 59,5 & 49,3 & 30,5 & 76,9 & 75,7 & 75,1 & 57,5 & 88,5 & 88,5 & 89,6 & 81,1 \\
\hline Bugarska & 46,8 & 48,5 & 41,7 & 26,5 & 79,0 & 74,7 & 76,4 & 58,4 & 90,3 & 87,3 & 86,7 & $\ldots$ \\
\hline Češka & 58,4 & 55,0 & 52,9 & 23,9 & 86,6 & 70,5 & 71,1 & 55,0 & 91,3 & 70,4 & 77,8 & 68,6 \\
\hline Njemačka & 66,5 & 55,3 & 49,2 & 31,0 & 82,4 & 75,0 & 68,4 & 54,9 & 90,8 & 85,3 & 81,8 & 69,1 \\
\hline Estonija & $\ldots$ & $\ldots$ & $\ldots$ & $\ldots$ & 84,7 & 79,9 & 74,4 & 61,2 & 90,8 & 89,0 & 84,2 & \\
\hline Grčka & 50,6 & 48,4 & 44,2 & 45,7 & 67,3 & 60,1 & 56,6 & 48,8 & 82,3 & 81,3 & 80,7 & 77,1 \\
\hline Hrvatska* & 38,2 & 68,2 & 46,4 & 50,0 & 50,2 & 78,2 & 74,3 & 65,8 & 80,3 & 92,1 & 96,6 & 90,0 \\
\hline Španjolska & 59,9 & 50,6 & 45,7 & 36,4 & 76,8 & 68,5 & 57,9 & 52,3 & 83,9 & 79,6 & 76,2 & 72,3 \\
\hline Francuska & 66,5 & 65,0 & 57,7 & 40,9 & 83,9 & 80,5 & 74,1 & 58,8 & 85,2 & 83,8 & 84,2 & 74,4 \\
\hline Italija & 53,8 & 45,7 & 35,2 & 26,1 & 74,2 & 68,2 & 63,3 & 54,5 & 77,6 & 75,0 & 80,5 & 75,5 \\
\hline Latvija & 62,2 & 49,0 & $\ldots$ & $\ldots$ & 79,3 & 80,3 & 77,8 & 65,4 & 90,7 & 89,2 & 82,9 & 94,4 \\
\hline Litva & $\ldots$ & $\ldots$ & $\ldots$ & $\ldots$ & 78,7 & 77,2 & 79,2 & 70,6 & 93,0 & 92,6 & 90,1 & 86,6 \\
\hline Mađarska & 50,2 & 50,3 & 41,6 & 20,2 & 81,1 & 68,7 & 67,9 & 43,8 & 93,6 & 72,7 & 81,7 & 71,4 \\
\hline Nizozemska & 66,4 & 61,5 & 58,6 & 43,1 & 87,6 & 77,3 & 78,6 & 68,9 & 91,9 & 87,3 & 88,1 & 81,6 \\
\hline Austrija & 71,0 & 66,9 & 56,8 & 43,1 & 85,7 & 82,8 & 74,1 & 63,6 & 90,0 & 85,8 & 83,8 & 70,2 \\
\hline Poljska & 37,9 & 45,0 & 45,1 & 35,8 & 69,1 & 66,4 & 63,9 & 58,1 & 90,0 & 84,7 & 85,9 & 86,7 \\
\hline Portugal & 71,1 & 73,9 & 72,6 & 59,0 & 75,5 & 81,4 & 85,2 & 79,1 & 86,2 & 90,4 & 91,2 & 89,6 \\
\hline Rumunjska & 55,9 & 53,1 & 49,9 & 42,4 & 73,7 & 74,9 & 72,0 & 61,5 & 90,6 & 92,3 & 93,4 & $\ldots$ \\
\hline Slovenija & 68,3 & 72,1 & 73,5 & 68,4 & 76,0 & 82,9 & 86,3 & 84,8 & 90,2 & 93,0 & 95,1 & 95,3 \\
\hline Slovačka & 39,5 & 42,5 & 40,0 & 16,9 & 81,4 & 70,6 & 70,1 & 59,3 & 92,7 & 82,2 & 78,8 & 64,9 \\
\hline Finska & 61,1 & 70,1 & 70,4 & 47,8 & 77,3 & 77,5 & 77,3 & 66,4 & 90,9 & 82,1 & 85,4 & 72,9 \\
\hline UK & 70,5 & 63,8 & 57,6 & 30,8 & 86,4 & 76,3 & 71,7 & 49,9 & 93,0 & 86,8 & 82,1 & 72,2 \\
\hline
\end{tabular}

Izvor: Eurostat (2010.), za Hrvatsku: izračun autora na temelju mikropodataka Ankete o radnoj snazi Državnoga zavoda za statistiku RH.

*Podaci za Hrvatsku odnose se na drugo tromjesečje 2007. i na dobnu skupinu od 20 do 39.

\section{Svrha rada i istraživačka pitanja}

Ovo se istraživanje temelji na obrazovanju kao mogućem činitelju vrlo niskoga fertiliteta u Hrvatskoj. Pitanje je kakva je veza između sve veće razine obrazovanja žena u Hrvatskoj i fertiliteta. Da bismo spoznali povezanost visokog obrazovanja

žena i fertiliteta, treba istražiti je li visoko obrazovanje izravno 
DRUŠ. ISTRAŽ. ZAGREB GOD. 20 (2011), BR. 1 (111)

STR. 25-46

ČIPIN, I.:

OBRAZOVANJE... povezano s fertilitetom ili je pak ta korelacija neizravna preko ostalih socioekonomskih varijabli. Svrha je rada ispitati postoji li i koliko je značajna razlika u dobi rađanja prvoga djeteta između žena s raznim stupnjevima obrazovanja. Isto tako, istražit će se koliko viši obrazovni status utječe na kvantum fertiliteta i je li tercijarno obrazovanje povezano s vrednotama i aktivnostima koje nisu kompatibilne s imanjem djece.

\section{OBRAZOVANJE I FERTILITET: TEORIJE I EMPIRIJSKA ISTRAŽIVANJA}

Veza između obrazovanja i fertiliteta je kompleksna (Martin-Garcia, 2008.). Teorijska objašnjenja utjecaja obrazovanja na fertilitet u demografskoj su literaturi pod snažnim utjecajem ekonomista i njihovih teorija. Prema vrlo utjecajnoj ekonomskoj teoriji fertiliteta (vidjeti: Becker, 1991.), razlozi za vrlo nizak fertilitet mogu se, među ostalim, tražiti u porastu razine obrazovanja i zaposlenosti žena. Unutar nove ekonomike kućanstva ${ }^{1}$ objašnjenje veze između razine obrazovanja i fertiliteta daje se preko efekta dohotka i efekta cijene. Navedena teorija naglašava da je efekt dohotka važniji kod muškaraca, a efekt cijene kod žena. Naime, obrazovaniji muškarci imaju veće mogućnosti za veću zaradu i ostvarenje boljega imovinskog statusa i, shodno tome, financijski su sposobniji uzdržavati obitelj i veći broj djece. Oni su ujedno ženama i privlačniji kao potencijalni partneri na tržištu braka. Kod žena je suprotna situacija. Visokoobrazovanim ženama je zamjena radnog mjesta kućanskim poslovima i brigom za djecu financijski neisplativa. Naime, kad nisu na tržištu rada zbog rađanja i podizanja djece, gube dohodak koji bi inače imale. Ova teorija naglašava i kako se ženi odgodom rađanja prvoga djeteta povećava financijska, ali i profesionalna, korisnost. Prema njoj, žene ne samo da žele završiti visoko obrazovanje nego i steći određenu poziciju na poslu prije nego što rode dijete.

Dakle, prema ekonomskim teorijama fertiliteta, ljudski kapital ima jednu od najvažnijih uloga u određivanju dobi rađanja (Gustafsson, 2001.). Činjenica je da su troškovi podizanja djece pod velikim utjecajem promjena u vrijednosti ženina vremena. Ekonomisti (Becker, 1991.) razloge za to nalaze u činjenici da troškovi ženina vremena kada rodi čine velik dio troškova u imanju djece. Nova ekonomika kućanstva daje okvir za proučavanje uloge ženina obrazovnog statusa u kontekstu odluka o fertilitetu. Prema toj tezi, troškovi podizanja djece za ženu koja se školuje uključuju tri vrste troškova: oportunitetne troškove vremena provedenog $\mathrm{u}$ brizi za djecu umjesto na tržištu rada, troškove opadanja vrijednosti stečenog obrazovanja i poslovnih vještina $u$ vremenu podizanja djece i izravne novčane troškove uzdržavanja djece (Cigno i 
DRUŠ. ISTRAŽ. ZAGREB GOD. 20 (2011), BR. 1 ( 1111$)$

STR. $25-46$

ČIPIN, I.:

OBRAZOVANJE... nomski troškovi imanja djece variraju prema fazama ženina života. Naime, oni nisu isti u svim fazama života, bez obzira na ostvareni stupanj obrazovanja (Gustafsson, 2001.). U razdoblju neposredno nakon završetka obrazovanja imanje djece može imati negativan utjecaj na poziciju na poslu i stvaranje temelja za građenje karijere, posebice za visokoobrazovane žene (Liefbroer i Corijn, 1999.; Gustafsson i sur., 2002.).

Sve veći obuhvat žena s visokim obrazovanjem i porast plaća smanjile su želju žena za brakom i djecom (Becker, 1991.). Prema Beckerovoj novoj ekonomici kućanstva, sve veća ekonomska neovisnost žena glavni je razlog odgađanja sklapanja braka za kasnije godine, smanjenoga broja brakova, kao i nestabilnih brakova. Taj teorijski pristup naglašava i koncept specijalizacije uloga između bračnih partnera. Naime, podjela rada između bračnih partnera - muškarac radi plaćeni posao, a žena neplaćeni posao u kućanstvu - prednost je za ženu s niskim stupnjem obrazovanja, koja nema velikih izgleda naći dobro plaćen posao na tržištu rada. Iz perspektive ove teorije, ženama s visokim stupnjem obrazovanja i s većim potencijalom za dobar posao i zaradu potreba i poticaj da uđu u brak niži su. Teorija o ekonomskoj neovisnosti žena, premda je logički konzistentna, nije dovoljno empirijski potvrđena. Dokazi o empirijskoj valjanosti teorije na agregatnoj razini (vidjeti npr: Billari i sur., 2002.) i oni na individualnoj razini (npr. Hoem, 1986.; Blossfeld i Huinink, 1991.) nisu pokazali da visokoobrazovane žene ne ulaze u brak, nego da ga samo odgađaju za kasnije. Neka empirijska istraživanja pokazuju da obrazovanje odgađa roditeljstvo, ali više zbog vremena koje se provede $\mathrm{u}$ obrazovnom sustavu nego zbog povećanoga ljudskog kapitala (Blossfeld i Huinink, 1991.; Blossfeld, 1995.). Kritičari te teorije (Oppenheimer, 1994.) naglašavaju da je teza o specijalizaciji uloga među partnerima zastarjela i u suvremenim uvjetima neodrživa.

Općenito se smatra da viša razina obrazovanja žena na individualnoj razini smanjuje fertilitet. Ovakva se generalizacija tada često preslikava na agregatnu razinu i drži se da je u onoj zemlji u kojoj je relativno više žena višega stupnja obrazovanja fertilitet niži. No takva generaliziranja u novije vrijeme više ne vrijede. I dok je ranije, u 1970-ima i 1980-ima, veza između fertiliteta i udjela visokoobrazovanih žena bila negativna, Castles je (2003.) na primjeru zemalja OECD-a pokazao da je u 1990-ima veza promijenila smjer u pozitivnu. Štoviše, razlike $u$ fertilitetu među ženama različita obrazovnog statusa danas nisu toliko izražene kao u prošlosti.

Tek se odnedavno počela istraživati veza između razine obrazovanja pojedinaca i namjeravanoga (željenoga) broja djece (Heiland i sur., 2005.). Veza između razine obrazovanja pojedinca i željenoga broja djece nipošto nije jednostavna. S jedne strane, može se tvrditi da su visokoobrazovani manje sklo- 
DRUŠ. ISTRAŽ. ZAGREB GOD. 20 (2011), BR. 1 (111)

STR. 25-46

ČIPIN, I.: OBRAZOVANJE... ni obiteljskom životu, više posvećeni poslu i karijeri, stoga se može očekivati da imaju manji broj djece. No istodobno možemo tvrditi da su danas, u vremenima ekonomske nesigurnosti i visokih financijskih troškova podizanja djece, visokoobrazovani zbog višega životnog standarda ekonomski sposobniji imati djecu. U literaturi se navode razni razlozi, odnosno ograničenja koja mogu sprječavati visokoobrazovane žene u ostvarenju željenoga fertiliteta (Heiland i sur., 2005.). Naime, visoki povrati na ulaganja u ljudski kapital, povećane mogućnosti na tržištu rada, otežano usklađivanje obiteljskoga i poslovnoga života, nejednaka raspodjela neplaćenoga rada među partnerima u kućanstvu samo su neki od ograničenja koja otežavaju ženama ostvarenje vlastitih fertilitetnih intencija (više o drugim razlozima: Cudina-Obradović i Obradović, 1999.).

Stavovi žena prema djeci i formiranju obitelji i obrazovni status negativno su korelirani (Barber i sur., 2002.). Dakle, ona žena čije su vrednote takve da je manje sklona imanju djece istodobno će više ulagati u vlastiti ljudski kapital produženim obrazovanjem. Prema teoriji druge demografske tranzicije (Van de Kaa, 1987., 2001.; Lesthaeghe, 1995.; Lesthaeghe i Surkyn, 1988.), očekujemo da bolje obrazovani teže manjem broju djece. Bolje obrazovani žele imati veće mogućnosti ostvarivanja karijere i individualnih preferencija, pa se može očekivati da je među visokoobrazovanima raširenije imanje manjega broja djece od onih koji imaju niže stupnjeve obrazovanja. Ova teorija, među ostalim, naglašava važnost tzv. postmaterijalističkih vrednota (vidjeti: Inglehart, 1997.) i kaže da su promjene u društvenom i demografskom ponašanju potaknute rastom vrijednosti individualne samorealizacije, zadovoljavanjem osobnih preferencija, liberalizmom i oslobađanjem od tradicionalnih snaga autoriteta, posebno religije. Sve su ove vrijednosti, kao što ova teorija tvrdi, bile povezane sa smanjenom sklonosti ulaska u brak, povećanjem broja razvoda, kohabitacije i izvanbračnih rađanja. Prema kulturološkom objašnjenju niskoga fertiliteta, unutar okvira teorije druge demografske tranzicije samoispunjenje je glavni cilj u životu, a imanje djece postaje sve manje važno u životima pojedinaca i parova. Kao rezultat toga ulazak u brak i imanje djece odgađaju se za kasnije godine života, sve dok se ostali ciljevi u životu, poput stjecanja željene razine obrazovanja i stjecanje zadovoljavajuće pozicije na tržištu rada, ne ostvare.

Jedan od tvoraca teorije druge demografske tranzicije, van de Kaa (1987.), identificirao je širenje individualizma, emancipaciju, sve veće individualne slobode i prava te tehnološki progres (dostupnost modernih sredstava kontracepcije) kao ključne činitelje pada fertiliteta u zapadnoj i sjevernoj Europi. Druga demografska tranzicija u zemljama zapadne Europe manifestirala se kroz generacije rođene u 1950-ima i 1960-ima. 
DRUŠ. ISTRAŽ. ZAGREB GOD. 20 (2011), BR. $1(111)$

STR. 25-46

ČIPIN, I.:

OBRAZOVANJE...

\section{METODA}

\section{Uzorak}

Među bivšim socijalističkim zemljama, Mađarska, Slovenija i Hrvatska bile su prve zemlje $u$ kojima se počeo širiti dio obilježja karakterističnih za drugu demografsku tranziciju, prije svega odgađanje rađanja prvoga djeteta. Neekonomske teorije, dakle, pokušavaju objašnjenja demografskih promjena naći prije svega u sustavu institucija, normi, vrednota, ponašanja, difuzija novih ideja i inovacija. Neki autori (Lesthaeghe i Surkyn, 2002.) vjeruju da će u dugom roku kulturološki činitelji u bivšim socijalističkim zemljama postati dominantni i preuzeti primat nad ekonomskima i onima povezanima s kriznim razdobljem nakon transformacije političkoga i gospodarskoga sustava. Drugi se (vidjeti npr. McDonald, 2000.) s time ne slažu. Evidentno je da je među razvijenim zemljama fertilitet veći u liberalnim nego u tradicionalnim društvima. Pitamo se onda zašto je to tako i zašto su društva koja zadrže tradicionalno ponašanje manje sposobna da se reproduciraju nego što su to liberalna društva. McDonald (2000.) tvrdi da to nije toliko povezano s rastom postmaterijalističkih vrednota i smatra da se ne smije adresirati krivnja na selektivnu grupu žena unutar jednoga društva zbog niskoga fertiliteta. Prije je, po McDonaldovu mišljenju, nizak fertilitet društveni fenomen povezan sa strukturama društvenih institucija, što je predmet proučavanja jedne druge teorije niskoga fertiliteta, što pak prelazi okvire ovoga rada.

Ovaj se rad temelji na podacima anketnog istraživanja koje se provodilo u Hrvatskoj od veljače do travnja 2007. godine. Istraživanje je provedeno opsežnim terenskim anketiranjem na reprezentativnom proporcionalnom kvotnom uzorku na svim područjima (županijama) Hrvatske. ${ }^{2}$ Istraživanjem je ispitana populacija zaposlenih žena u Hrvatskoj od 20 do 39 godina, neovisno o bračnom statusu i imanju / neimanju djece. Konačni uzorak čini 1309 zaposlenih žena, a ukupno je anketirano 1500 ispitanica. ${ }^{3}$ Kao istraživački instrument sastavljena je "Anketa o zaposlenosti žena i fertilitetu", koja je imala 52 pitanja, a koja su obuhvatila široku problematiku s kojom se zaposlene žene suočavaju kada žele imati djecu. Anketom se velikim dijelom mogu empirijski ispitati relevantne činjenice istaknute u ciljevima ovoga rada.

\section{Varijable i metode obradbe podataka}

Povezanost obrazovnoga statusa i vremena rađanja prvoga djeteta analizira se na agregatnoj razini. S druge strane, veza kvantuma fertiliteta i obrazovanja ispituje se mikropodacima 
DRUŠ. ISTRAŽ. ZAGREB GOD. 20 (2011), BR. 1 (111)

STR. 25-46

ČIPIN, I.:

OBRAZOVVANJE... ljenoj statističkoj tehnici, uzete su nezavisne i zavisne varijable od interesa. Zavisne varijable upotrijebljene $u$ analizi jesu:

1) Broj djece, tj. ostvareni fertilitet. Pitanjima o tome jesu li rodile i koliko, konstruirali smo četiri kategorije varijable ostvareni fertilitet: $0,1,2$ te 3 i više djece.

2) Mjesečna neto primanja ispitanice su upisivale $u$ upitnik kao numeričku (kontinuiranu) vrijednost.

3) Važnost određenih životnih prioriteta te materijalističkih i postmaterijalističkih vrijednosti (ispitanice su procjenjivale važnost na ljestvici od pet stupnjeva, gdje je $5=\mathrm{vr}-$ lo važno, $4=$ važno, $3=$ ni važno ni nevažno, $2=$ nevažno i 1 = sasvim nevažno).

Nezavisna varijabla u svim analizama jest razina obrazovanja. Radi lakše obradbe iz anketnog smo upitnika napravili kategorijalnu varijablu sa tri kategorije: primarno, sekundarno i tercijarno obrazovanje ispitanica. Osim razine obrazovanja, još smo se koristili dodatnim kontrolnim varijablama - dobi i partnerskim statusom. Dob smo konstruirali kao kategorijalnu varijablu sa dvije kategorije (mlađe, od 20 do 29, te starije, od 30 do 39), a partnerski status dvjema kategorijama: u partnerstvu (u koje smo uključili ispitanice u braku i izvanbračnoj zajednici) i nisu u partnerstvu (neudane, udovice i rastavljene).

$\mathrm{U}$ analizi rezultata primijenjene su metode univarijatne, bivarijatne i multivarijatne statistike: neparametarski hi-kvadrat test, jednosmjerna analiza varijance (ANOVA), post-hoc analiza (i to dva najkonzervativnija testa - Scheffeov i Tamhaneov T2, ovisno o homogenosti varijance) i multinomna logistička regresija. Radi preglednosti, agregatni podaci o vremenu rađanja prikazani su grafički.

\section{REZULTATI}

\section{Deskriptivna statistika - agregatni podaci}

Prije nego što prijeđemo na glavnu analizu, pogledajmo najprije agregatne rezultate na temelju podataka Državnoga zavoda za statistiku Republike Hrvatske. Uloga obrazovanja u smanjenju fertiliteta u Hrvatskoj sigurno je značajna, ali je prilično teško kvantificirati taj efekt. Obrazovna stratifikacija formiranja obitelji sigurno je prisutna i u Hrvatskoj. No najprije pogledajmo obrazovni status žena u Hrvatskoj od 20 do 39 godina. Prema rezultatima Popisa stanovništva iz 1991. i 2001., udio žena u promatranim dobnim skupinama koje imaju tercijarno obrazovanje porastao je (Tablica 2). No, istodobno, još se više smanjio udio onih koje imaju samo osnovno obrazovanje ili uopće nemaju nikakvo. ${ }^{4}$ Dakle, kao što agregatna statistika pokazuje, žene u Hrvatskoj u glavnim reproduktivnim dobnim skupinama sve su obrazovanije. 
OTABLICA 2

Obrazovna struktura ženskoga stanovništva Hrvatske prema odabranim dobnim grupama, Popisi iz 1991. i 2001 . (u \%)

GRAFIKON Prosječna dob pri prvom porodu u Hrvatskoi prema stupniu obrazovanja 1988., 1998. i 2008. godine

\begin{tabular}{crrr}
\hline & $\begin{array}{c}\text { Osnovna } \\
\text { škola i manje }\end{array}$ & Srednja škola & \multicolumn{2}{c}{$\begin{array}{l}\text { Više i visoko } \\
\text { obrazovanje }\end{array}$} \\
\hline 1991. & & & \\
$20-24$ & 23,1 & 71,9 & 4,6 \\
$25-29$ & 27,0 & 57,4 & 15,3 \\
$30-34$ & 34,2 & 49,9 & 15,6 \\
$35-39$ & 43,4 & 41,8 & 14,4 \\
2001. & & & \\
$20-24$ & 10,5 & 84,1 & 4,9 \\
$25-29$ & 16,0 & 63,1 & 20,3 \\
$30-34$ & 20,5 & 60,1 & 19,0 \\
$35-39$ & 23,9 & 57,7 & 18,0 \\
\hline
\end{tabular}

Napomena: Iznos do 100\% odnosi se na nepoznate. Izvor: DZS (2001.)

Ako obrazovanje žena uzmemo kao indikator većega sudjelovanja na tržištu rada i sklonosti k obitelji konkurentnim životnim aktivnostima, tada možemo reći da postoji pozitivna veza između razine obrazovanja i dobi rađanja prvoga djeteta. Hrvatska ulazi u grupu zemalja u kojima je dob rađanja prvoga djeteta znatno povećana u zadnjih nekoliko desetljeća. Pri tome treba naglasiti da se dobna granica pomaknula i kod žena s nižim i kod onih s višim stupnjem obrazovanja. Od 1988. do 2008. žene koje imaju primarno obrazovanje u Hrvatskoj rađale su prvo dijete u prosjeku sa $22-23$ godine, dok su ga visokoobrazovane imale u prosjeku sa 28 - 30 godina. Razlika između žena koje imaju niži stupanj obrazovanja i onih sa srednjom stručnom spremom bila je 1988. godine dvije godine i s vremenom se povećala. Istodobno, razlika u dobi prvoga poroda između žena koje imaju završenu srednju školu i onih s fakultetskim obrazovanjem bila je stabilna na razini od četiri godine.

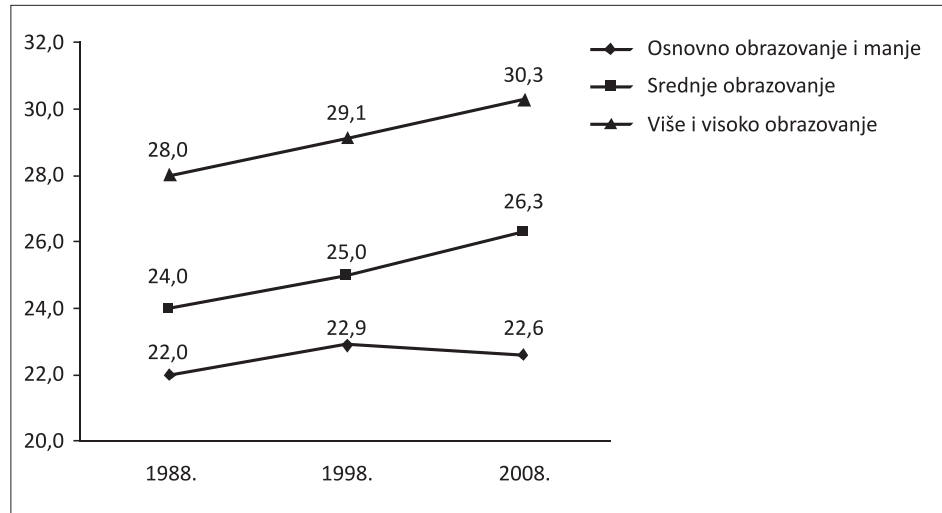

Izvor: Izračun autora na temelju internih publikacija Državnoga zavoda za statistiku RH 


\section{Pronalasci iz anketnog istraživanja}

Obrazovanje djeluje ne samo na tempo (vrijeme rađanja) nego i na kvantum (broj djece) fertiliteta. Rezultati iz ankete pokazuju da postoje značajne razlike $\mathrm{u}$ fertilitetu među zaposlenim ženama različita stupnja obrazovanja $\left(\chi^{2}=66,973\right.$; $\mathrm{p}<0,001)$. Očito je da je fertilitetno ponašanje žena s najnižim i najvišim stupnjevima obrazovanja sasvim različito. I dok je udio ispitanica s primarnim obrazovanjem koje nemaju djecu manji od 15\%, on je kod ispitanica koje su završile neki stupanj tercijarnog obrazovanja viši od 50\% (vidjeti Tablicu 3).

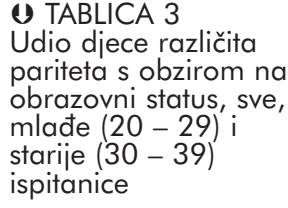
Očigledne razlike postoje i kod ostalih pariteta. Značajne razlike pronađene su kad je analiza provedena posebno za mlađe i starije ispitanice. Veću smo razliku našli kod ispitanica starih 30 i više godina, gdje svaka treća zaposlena žena s tercijarnim obrazovanjem nije rodila.

\begin{tabular}{llrrrr}
\hline Obrazovanje & & \multicolumn{2}{c}{ Rodile djece (u \%) } \\
\cline { 3 - 6 } & & Bez djece & Jedno & Dvoje & Troje i više \\
\hline \multirow{2}{*}{ Primarno } & Mlađe & 33,3 & 44,4 & 22,2 & 0,0 \\
& Starije & 7,4 & 7,4 & 44,4 & 40,7 \\
& Sve & 13,9 & 16,7 & 38,9 & 30,6 \\
\multirow{5}{*}{ Sekundarno } & Mlađe & 70,5 & 19,4 & 9,3 & 0,8 \\
& Starije & 18,8 & 23,1 & 42,0 & 16,1 \\
& Sve & 44,6 & 21,3 & 25,7 & 8,4 \\
\multirow{5}{*}{ Tercijarno } & Mlađe & 82,7 & 13,7 & 3,5 & 0,0 \\
& Starije & 33,9 & 26,7 & 33,1 & 6,4 \\
& Sve & 57,0 & 20,5 & 19,1 & 3,4 \\
\hline
\end{tabular}

mlađe $\left(\chi^{2}=22,275 ; \mathrm{p}<0,05\right) ;$ starije $\left(\chi^{2}=51,408 ; \mathrm{p}<0,001\right)$

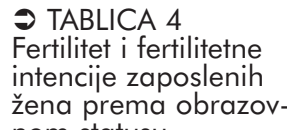
žena prema obrazovnom statusu

\begin{tabular}{lccr}
\hline & \multicolumn{2}{c}{ Prosječan broj djece } \\
\cline { 2 - 4 } Obrazovanje (N) & Aktualni* $^{*}$ & Željeni** $^{* *}$ & $\begin{array}{r}\text { Aktualni } \\
\text { +željeni }\end{array}$ \\
\hline Primarno (30) & 1,90 & 0,57 & 2,47 \\
Sekundarno (568) & 1,04 & 1,13 & 2,17 \\
Tercijarno (338) & 0,74 & 1,41 & 2,15 \\
Ukupno (936) & 0,96 & 1,21 & 2,17 \\
\hline
\end{tabular}

${ }^{*} \mathrm{~F}(2,933)=25,384, \mathrm{p}<0,001 ;{ }^{*} \mathrm{~F}(2,933)=14,313, \mathrm{p}<0,001$

Kvantum fertiliteta ispitanica također se razlikuje s obzirom na obrazovni status. Iz Tablice $4^{5}$ vidi se da su ispitanice s primarnim obrazovanjem rodile, $u$ prosjeku, najviše djece $(1,90)$. Ispitanice s tercijarnim stupnjem obrazovanja rodile 
DRUŠ. ISTRAŽ. ZAGREB GOD. 20 (2011), BR. $1(111)$

STR. $25-46$

ČIPIN, I.:

OBRAZOVANJE..

(1) TABLICA 5

Prosječna mjesečna neto primanja (u kn) ispitanica s obzirom na obrazovni status $\mathrm{su}, \mathrm{u}$ prosjeku, najmanje djece $(0,74)$. No kod njih je pak najviši željeni broj $(1,41)$. Premda su rezultati jednosmjerne analize varijance (ANOVA) pokazali postojanje statistički značajne razlike između aktualnoga i željenoga broja djece prema obrazovnom statusu, ono što je indikativno jest da gotovo nema razlike između ispitanica sa sekundarnim i tercijarnim obrazovanjem, kada zbrojimo aktualni i željeni broj djece. Jedino što ispitanice sa sekundarnim obrazovanjem imaju veći aktualni kvantum, jer im je vrijeme rađanja (tempo fertiliteta), kao što smo vidjeli, bilo nekoliko godina ranije. Pitanje je hoće li konačni kvantum biti isti za obje skupine ispitanica.

Da bismo istražili razliku između prosječnih mjesečnih neto primanja ispitanica s obzirom na obrazovni status, proveli smo jednofaktorsku analizu varijance, koja je pokazala postojanje statistički značajnih razlika (vidjeti Tablicu 5). Post-hoc Scheffeov test pokazao je da su razlike u plaći između žena s tercijarnim obrazovanjem i ostalih velike i statistički značajne $(\mathrm{p}<0,001)$, posebice za one mlađe na počecima karijere.

\begin{tabular}{|c|c|c|c|c|c|}
\hline \multirow[b]{2}{*}{ Prosječna plaća } & \multicolumn{5}{|c|}{ Obrazovanje } \\
\hline & Primarno & Sekundarno & Tercijarno & $\mathrm{df}$ & $\mathrm{F}$ \\
\hline Sve ispitanice & 2328,24 & 3229,17 & 4879,19 & $2 / 1111$ & $128,332^{* * *}$ \\
\hline Mlađe (20-29) & 2155,56 & 3077,62 & 4311,24 & $2 / 531$ & $46,961^{* * *}$ \\
\hline Starije (30-39) & 2390,40 & 3375,88 & 5395,75 & $2 / 577$ & $86,295^{* * *}$ \\
\hline
\end{tabular}

$* * * \mathrm{p}<0,001$

Stavovi i vrednote sve su važniji čimbenici u objašnjenju niskoga fertiliteta. Što je više žena s tercijarnim obrazovanjem, stavovi će biti sve liberalniji, pa izjave tipa "muškarci rade, žene u kući" sigurno neće biti prihvaćene. U Tablicama 6 i 7 prikazani su rezultati jednosmjerne analize varijance (ANOVA) i post-hoc testova, $\mathrm{tj}$. prikazane su razlike u odgovorima između ispitanica različita obrazovnog statusa s obzirom na pojedine životne prioritete, odnosno materijalističke i postmaterijalističke vrijednosti. Budući da je napravljeno po deset jednosmjernih ANOVA, upotrebom Bonferroni-prilagodbe uzeli smo prilagođenu razinu značajnosti $(\mathrm{p}<0,005)$ kako bismo smanjili rizik od pogreške tipa 1 .

Razlika u prioritetu od kojeg polazimo (imanje djece) ne postoji. Isto tako nije nađena statistički značajna razlika u materijalističkim vrednotama (imanje dovoljno novca, rješavanje stambenoga pitanja i sl.), koje su ispitanicama svih obrazovnih stratuma, u specifičnim hrvatskim socioekonomskim uvjetima, očito podjednako važne. S druge strane, statistički značajne razlike postoje u većini postmaterijalističkih vrednota i sklonije su im ispitanice s tercijarnim obrazovanjem. 
(1) TABLICA 6

Važnost pojedinih životnih prioriteta razlike s obzirom na stupanj obrazovanja
Žene s višim razinama obrazovanja u većoj mjeri teže $\mathrm{k}$ samoispunjenju, što indirektno utječe na kasnije sklapanje braka i/li kohabitacije i kasnije rađanje prvoga djeteta. Posebno se ističu samoispunjenje i samorealizacija na profesionalnoj razini, jer se ženama s višim razinama obrazovanja pružaju veće mogućnosti za promociju i napredovanje na poslu. Isto tako visokoobrazovane žene žele više putovati i imati više vremena za sebe i svoje prijatelje, što su aktivnosti koje su u svojevrsnom konfliktu s rađanjem i podizanjem djece.

\begin{tabular}{|c|c|c|c|c|c|}
\hline Prioriteti & Obrazovanje & $\mathrm{M}$ & SD & $\begin{array}{l}\text { Omnibus } \\
\text { F test }\end{array}$ & $\begin{array}{l}\text { Post-hoc test } \\
\text { (Scheffeov ili Tamhaneov) }\end{array}$ \\
\hline Imati djecu & $\begin{array}{l}\text { primarno } \\
\text { sekundarno } \\
\text { tercijarno }\end{array}$ & $\begin{array}{l}4,51 \\
4,62 \\
4,57\end{array}$ & $\begin{array}{l}0,51 \\
0,62 \\
0,69\end{array}$ & 1,572 & nije sig. \\
\hline $\begin{array}{l}\text { Napredovati u poslu } \\
\text { koji želim raditi }\end{array}$ & $\begin{array}{l}\text { primarno } \\
\text { sekundarno } \\
\text { tercijarno }\end{array}$ & $\begin{array}{l}4,17 \\
4,17 \\
4,30\end{array}$ & $\begin{array}{l}0,79 \\
0,75 \\
0,68\end{array}$ & $5,408^{*}$ & $\begin{array}{l}\text { sekundarno vs. tercijarno } \\
\text { sig. } \mathrm{p}<0,01\end{array}$ \\
\hline Bogato se udati & $\begin{array}{l}\text { primarno } \\
\text { sekundarno } \\
\text { tercijarno }\end{array}$ & $\begin{array}{l}2,44 \\
2,24 \\
2,07\end{array}$ & $\begin{array}{l}1,13 \\
1,01 \\
0,96\end{array}$ & $5,597^{*}$ & $\begin{array}{l}\text { sekundarno vs. tercijarno } \\
\text { sig. } \mathrm{p}<0,05\end{array}$ \\
\hline $\begin{array}{l}\text { Steći titule (magi- } \\
\text { sterij i doktorat) }\end{array}$ & $\begin{array}{l}\text { primarno } \\
\text { sekundarno } \\
\text { tercijarno }\end{array}$ & $\begin{array}{l}2,58 \\
2,69 \\
3,21\end{array}$ & $\begin{array}{l}1,16 \\
0,99 \\
1,04\end{array}$ & $39,453^{*}$ & $\begin{array}{l}\text { primarno vs. tercijarno, } \\
\text { sig. } \mathrm{p}<0,01 \text {; sekundarno } \\
\text { vs. tercijarno, sig. } \mathrm{p}<0,001\end{array}$ \\
\hline $\begin{array}{l}\text { Rješavanje stam- } \\
\text { benoga pitanja }\end{array}$ & $\begin{array}{l}\text { primarno } \\
\text { sekundarno } \\
\text { tercijarno }\end{array}$ & $\begin{array}{l}4,53 \\
4,68 \\
4,68\end{array}$ & $\begin{array}{l}1,00 \\
0,60 \\
0,60\end{array}$ & 1,117 & nije sig. \\
\hline Biti sama & $\begin{array}{l}\text { primarno } \\
\text { sekundarno } \\
\text { tercijarno }\end{array}$ & $\begin{array}{l}1,79 \\
1,86 \\
1,86\end{array}$ & $\begin{array}{l}0,84 \\
0,99 \\
1,02\end{array}$ & 0,080 & nije sig. \\
\hline $\begin{array}{l}\text { Naći partnera koji } \\
\text { me razumije }\end{array}$ & $\begin{array}{l}\text { primarno } \\
\text { sekundarno } \\
\text { tercijarno }\end{array}$ & $\begin{array}{l}4,53 \\
4,65 \\
4,74\end{array}$ & $\begin{array}{l}0,81 \\
0,65 \\
0,52\end{array}$ & 3,973 & nije sig. \\
\hline Emancipiranost & $\begin{array}{l}\text { primarno } \\
\text { sekundarno } \\
\text { tercijarno }\end{array}$ & $\begin{array}{l}3,23 \\
3,69 \\
3,85\end{array}$ & $\begin{array}{l}1,06 \\
0,97 \\
0,90\end{array}$ & $8,702^{*}$ & $\begin{array}{l}\text { primarno vs. tercijarno, } \\
\text { sig. } \mathrm{p}<0,01 \text {; sekundarno } \\
\text { vs. tercijarno, sig. } \mathrm{p}<0,05\end{array}$ \\
\hline $\begin{array}{l}\text { Imati lagodan život } \\
\text { bez stresa }\end{array}$ & $\begin{array}{l}\text { primarno } \\
\text { sekundarno } \\
\text { tercijarno }\end{array}$ & $\begin{array}{l}4,34 \\
4,31 \\
4,28\end{array}$ & $\begin{array}{l}0,84 \\
0,77 \\
0,80\end{array}$ & 0,263 & nije sig. \\
\hline Putovanja & $\begin{array}{l}\text { primarno } \\
\text { sekundarno } \\
\text { tercijarno }\end{array}$ & $\begin{array}{l}3,14 \\
3,36 \\
3,77\end{array}$ & $\begin{array}{l}1,26 \\
0,99 \\
0,89\end{array}$ & $29,412^{*}$ & $\begin{array}{l}\text { primarno vs. tercijarno, } \\
\text { sig. } \mathrm{p}<0,05 \text {; sekundarno } \\
\text { vs. tercijarno, sig. } \mathrm{p}<0,001\end{array}$ \\
\hline
\end{tabular}

${ }^{*} \mathrm{p}<0,005$ 


\begin{tabular}{|c|c|c|c|c|c|}
\hline \multirow{2}{*}{$\begin{array}{l}\text { (U) TABLICA } 7 \\
\text { Važnost materijalistič- } \\
\text { kih i postmaterijali- } \\
\text { stičkih vrijednosti, } \\
\text { razlike s obzirom na } \\
\text { stupanj obrazovanja } \\
\text { Vrednote }\end{array}$} & \multirow{2}{*}{ Obrazovanje } & & & & \multirow[b]{2}{*}{$\begin{array}{l}\text { Post-hoc test } \\
\text { (Scheffeov ili Tamhaneov) }\end{array}$} \\
\hline & & M & SD & $\begin{array}{l}\text { Omnibus } \\
\text { F test }\end{array}$ & \\
\hline $\begin{array}{l}\text { Imati dovoljno } \\
\text { vremena za sebe } \\
\text { i svoje interese }\end{array}$ & $\begin{array}{l}\text { primarno } \\
\text { sekundarno } \\
\text { tercijarno }\end{array}$ & $\begin{array}{l}4,03 \\
4,22 \\
4,33\end{array}$ & $\begin{array}{l}0,77 \\
0,64 \\
0,58\end{array}$ & $7,481^{*}$ & $\begin{array}{l}\text { primarno vs. tercijarno, } \\
\text { sig. } \mathrm{p}<0,05 \text {; sekundarno vs. } \\
\text { tercijarno, sig. } \mathrm{p}<0,01\end{array}$ \\
\hline $\begin{array}{l}\text { Živjeti s partnerom } \\
\text { u skladu }\end{array}$ & $\begin{array}{l}\text { primarno } \\
\text { sekundarno } \\
\text { tercijarno }\end{array}$ & $\begin{array}{l}4,24 \\
4,57 \\
4,69\end{array}$ & $\begin{array}{l}0,74 \\
0,64 \\
0,56\end{array}$ & $12,379^{*}$ & $\begin{array}{l}\text { primarno vs. sekundarno, } \\
\text { sig. } \mathrm{p}<0,05 \text {; primarno vs. terci- } \\
\text { jarno, sig. } \mathrm{p}<0,01 \text {; sekundarno } \\
\text { vs. tercijarno, sig. } \mathrm{p}<0,001\end{array}$ \\
\hline $\begin{array}{l}\text { Pružati sigurnost } \\
\text { svojim bližnjima }\end{array}$ & $\begin{array}{l}\text { primarno } \\
\text { sekundarno } \\
\text { tercijarno }\end{array}$ & $\begin{array}{l}4,64 \\
4,65 \\
4,65\end{array}$ & $\begin{array}{l}0,64 \\
0,54 \\
0,49\end{array}$ & 0,015 & nije sig. \\
\hline $\begin{array}{l}\text { Biti poštovana i } \\
\text { ugledna izvan } \\
\text { svoje obitelji }\end{array}$ & $\begin{array}{l}\text { primarno } \\
\text { sekundarno } \\
\text { tercijarno }\end{array}$ & $\begin{array}{l}4,06 \\
4,03 \\
4,05\end{array}$ & $\begin{array}{l}0,92 \\
1,12 \\
0,69\end{array}$ & 0,118 & nije sig. \\
\hline $\begin{array}{l}\text { Imati dovoljno vre- } \\
\text { mena za svoje } \\
\text { prijatelje }\end{array}$ & $\begin{array}{l}\text { primarno } \\
\text { sekundarno } \\
\text { tercijarno }\end{array}$ & $\begin{array}{l}3,69 \\
4,02 \\
4,11\end{array}$ & $\begin{array}{l}0,67 \\
0,63 \\
0,56\end{array}$ & $9,267^{*}$ & $\begin{array}{l}\text { primarno vs. sekundarno, sig. } \\
\mathrm{p}<0,05 \text {; primarno vs. tercijarno, } \\
\text { sig. } \mathrm{p}<0,01 \text {; sekundarno vs. terci- } \\
\text { jarno, sig. } \mathrm{p}<0,05\end{array}$ \\
\hline $\begin{array}{l}\text { Imati dovoljno nov- } \\
\text { ca i prihoda }\end{array}$ & $\begin{array}{l}\text { primarno } \\
\text { sekundarno } \\
\text { tercijarno }\end{array}$ & $\begin{array}{l}4,20 \\
4,30 \\
4,28\end{array}$ & $\begin{array}{l}0,63 \\
0,60 \\
0,56\end{array}$ & 0,584 & nije sig. \\
\hline $\begin{array}{l}\text { Imati godišnji od- } \\
\text { mor barem jednom } \\
\text { u godini }\end{array}$ & $\begin{array}{l}\text { primarno } \\
\text { sekundarno } \\
\text { tercijarno }\end{array}$ & $\begin{array}{l}4,69 \\
4,59 \\
4,59\end{array}$ & $\begin{array}{l}0,53 \\
0,56 \\
0,54\end{array}$ & 0,493 & nije sig. \\
\hline Živjeti u lijepoj kući & $\begin{array}{l}\text { primarno } \\
\text { sekundarno } \\
\text { tercijarno }\end{array}$ & $\begin{array}{l}3,72 \\
3,74 \\
3,72\end{array}$ & $\begin{array}{l}0,88 \\
0,84 \\
0,78\end{array}$ & 0,065 & nije sig. \\
\hline $\begin{array}{l}\text { Težnja k } \\
\text { samoispunjenju }\end{array}$ & $\begin{array}{l}\text { primarno } \\
\text { sekundarno } \\
\text { tercijarno }\end{array}$ & $\begin{array}{l}3,74 \\
4,00 \\
4,18\end{array}$ & $\begin{array}{l}0,92 \\
0,76 \\
0,71\end{array}$ & $11,471^{*}$ & $\begin{array}{l}\text { primarno vs. tercijarno, } \\
\text { sig. } \mathrm{p}<0,05 \text {; sekundarno vs. } \\
\text { tercijarno, } \mathrm{p}<0,001\end{array}$ \\
\hline $\begin{array}{l}\text { Biti zadovoljna } \\
\text { na poslu }\end{array}$ & $\begin{array}{l}\text { primarno } \\
\text { sekundarno } \\
\text { tercijarno }\end{array}$ & $\begin{array}{l}4,52 \\
4,54 \\
4,52\end{array}$ & $\begin{array}{l}0,57 \\
0,52 \\
0,55\end{array}$ & 0,210 & nije sig. \\
\hline
\end{tabular}

${ }^{*} \mathrm{p}<0,005$

\section{Rezultati logističke regresije}

Napravljena su dva modela multinomne logističke regresije. U prvom je ispitana prediktivna sposobnost obrazovnoga statusa da objasni šanse pripadnosti određenoj fertilitetnoj kategoriji. U drugom modelu, dodane su dvije kontrolne varijable 
DRUŠ. ISTRAŽ. ZAGREB GOD. 20 (2011),

BR. 1 (111)

STR. 25-46

ČIPIN, I.:

OBRAZOVANJE...

DTABLICA 8

Deskriptivna

statistika uzorka koje su značajno poboljšale model. U Tablici 8 prikazana je deskriptivna analiza rezultata logističke regresije, a u Tablici 9 nalaze se omjeri šansi uz logističke koeficijente. Referentna kategorija jesu ispitanice bez djece. Rezultati iz multinomne logističke regresije pokazuju da je imanje (većega broja) djece povezano s nižim obrazovnim statusom (model 1). Uključivanjem dodatnih kontrolnih varijabli (model 2) šansa da žena sa sekundarnim obrazovanjem ima dvoje djece (nasuprot nula) gotovo je tri (točnije 2,83 ) puta veća nego žena s tercijarnim obrazovanjem.

\begin{tabular}{|c|c|c|c|c|}
\hline \multirow{3}{*}{$\begin{array}{l}\text { TABLICA } 8 \\
\text { Deskriptivna } \\
\text { statistika uzorka }\end{array}$} & & & & \\
\hline & \multicolumn{2}{|l|}{ Varijable } & $\mathrm{N}$ & $\%$ \\
\hline & Broj djece & Nula & 627 & 48,2 \\
\hline & & Jedno & 272 & 20,9 \\
\hline & & Dvoje & 309 & 23,7 \\
\hline & & Troje i više & 94 & 7,2 \\
\hline & Obrazovanje & Primarno & 36 & 2,8 \\
\hline & & Sekundarno & 791 & 60,7 \\
\hline & & Tercijarno & 475 & 36,5 \\
\hline \multirow{4}{*}{$\begin{array}{l}\text { (1) TABLICA 9 } \\
\text { Omjeri šansi imanja } \\
\text { određenog broja djece } \\
\text { (bez djece - referentna } \\
\text { kategorija) }\end{array}$} & Dob & $20-29$ & 628 & 48,2 \\
\hline & & $30-34$ & 674 & 51,8 \\
\hline & Partnerstvo & Nisu u partnerstvu & 447 & 34,3 \\
\hline & & U partnerstvu & 855 & 65,7 \\
\hline
\end{tabular}

\begin{tabular}{|c|c|c|c|c|c|c|}
\hline & Jedno & & Dvoje & & Troje i vi & \\
\hline & model 1 & model 2 & model 1 & model 2 & model 1 & model 2 \\
\hline Obrazovanje & & & & & & \\
\hline primarno & 3,33 & $4,31^{* *}$ & $8,37^{* * *}$ & $13,89^{* * *}$ & $37,40^{* * *}$ & $68,55^{* * *}$ \\
\hline sekundarno & 1,32 & $1,79^{*}$ & $1,72^{* * *}$ & $2,83^{* * *}$ & $3,22^{* * *}$ & $5,69 * * *$ \\
\hline tercijarno & 1 & 1 & 1 & 1 & 1 & 1 \\
\hline Dob & & & & & & \\
\hline $20-29$ & & $* * *$ & & $26^{* * *}$ & & $0,01^{* * *}$ \\
\hline $30-39$ & 1 & & 1 & & & 1 \\
\hline Partnerski status & & & & & & \\
\hline Nisu u partnerstvu & & $* * *$ & & $04^{* * *}$ & & $0,03^{* * *}$ \\
\hline U partnerstvu & 1 & & 1 & & & 1 \\
\hline${ }^{*} \mathrm{p}<0,05,{ }^{* *} \mathrm{p}<0,01$, * & $\mathrm{p}<0,001$ & Napomena: & $\begin{array}{l}\text { Pseudo } \\
\text { Cox i Sn } \\
\text { Nagelke }\end{array}$ & $\begin{array}{l}\text { kvadrat: } \\
1 \\
\text { e }\end{array}$ & $\begin{array}{l}\text { model } 1 \\
0,045 \\
0,049\end{array}$ & $\begin{array}{l}\text { model } 2 \\
0,475 \\
0,521\end{array}$ \\
\hline
\end{tabular}

\section{RASPRAVA I IMPLIKACIJE}

Neki autori (Kohler i sur., 2002.; McDonald, 2000.) naglašavaju važnost globalizacije ekonomije i odgovarajućih promjena na tržištu rada u zadnja dva desetljeća. Naime, niskokvalificirani, ali relativno dobro plaćeni i sigurni, poslovi za one koji ranije završe školovanje uglavnom su nestali i zamijenili su ih 
DRUŠ. ISTRAŽ. ZAGREB GOD. 20 (2011), BR. $1(111)$

STR. $25-46$

ČIPIN, I.:

OBRAZOVANJE... sigurnosti. To je razdoblje ekonomske nesigurnosti natjeralo mlade ljude, osobito u postsocijalističkim i tranzicijskim ekonomijama kakva je i Hrvatska, da se na neki način koliko-toliko osiguraju ulaganjem u sebe. Ulaganjem u vlastiti ljudski kapital, tj. u obrazovanje i razvoj karijere, jednostavno nemaju vremena da prije toga razmišljaju o djeci. Sve to utječe na odluku da se kasnije stupi u brak ili izvanbračnu zajednicu i odgodi rađanje.

Sve viša razina obrazovanja žena u Hrvatskoj djeluje na tempo fertiliteta, odnosno odgađanje rađanja na sve kasnije godine života. Rezultati na agregatnoj razini pokazali su da je u zadnjih nekoliko desetljeća u Hrvatskoj došlo do porasta prosječne dobi pri prvom porođaju, posebice obrazovanijih žena. Općenito vrijedi da bolje obrazovani sklapaju partnerstva i imaju djecu kasnije u životu od onih manje obrazovanih (vidjeti npr. Liefbroer i Corijn, 1999.), što dodatno smanjuje izglede za imanje većega broja djece, jer im je reproduktivno razdoblje obrazovanjem skraćeno. Zbog duljega školovanja, ekonomska i osobna neovisnost žena koje imaju tercijarno obrazovanje stječe se u srednjim dvadesetima. To neminovno dovodi do odgode rađanja prvoga djeteta u odnosu na žene sa sekundarnim obrazovanjem, i to za barem četiri-pet godina, koliko otprilike, u prosjeku, dulje traje obrazovanje žena koje nastavljaju školovanje nakon završetka srednjoškolskog obrazovanja. Neka istraživanja u europskim zemljama pokazala su da je negativan utjecaj razine obrazovanja na fertilitet s vremenom oslabio, pa čak i promijenio smjer (Kravdal, 2001.). Nekoliko je studija našlo negativan i statistički značajan učinak obrazovnoga statusa na stope rađanja prvoga djeteta (Liefbroer i Corijn, 1999.; Martin-Garcia i Baizan, 2006.; Nicoletti i Tanturri, 2008.). Drugim riječima, pozitivna je veza između obrazovanja i dobi rađanja prvoga djeteta, što implicira da visokoobrazovane žene odgađaju rađanje za kasnije godine života $u$ usporedbi sa ženama s nižim stupnjem obrazovanja. Suprotno tome, druga istraživanja našla su pozitivan i statistički značajan učinak obrazovanja na fertilitet prvoga reda rađanja (Kreyenfeld, 2002.; Lappegard i Rønsen, 2005.). To objašnjavaju činjenicom da visokoobrazovane žene odgađaju rađanja tijekom školovanja, ali to nadoknade i dostignu niskoobrazovane žene nakon završetka školovanja. U nekima, većinom skandinavskim, zemljama potvrđeno je da žene s višim stupnjem obrazovanja imaju veće stope rađanja drugoga djeteta od niže obrazovanih žena (Olah, 2003.; Koppen, 2006.; Gerster i sur., 2007.), no one su zasad iznimka među europskim zemljama niskoga fertiliteta.

Prilikom oblikovanja mjera pronatalitetnih politika trebalo bi voditi računa o tome da najveća razlika između željeno- 
DRUŠ. ISTRAŽ. ZAGREB GOD. 20 (2011), BR. 1 (111)

STR. 25-46

ČIPIN, I.: OBRAZOVANJE...

\section{BILJEŠKE}

ga i ostvarenoga broja djece žena u središnjoj reproduktivnoj dobi jest upravo kod visokoobrazovanih, što su rezultati ove ankete i potvrdili. Rezultati su također pokazali da visoko obrazovanje nije izravno povezano s nižom fertilitetnom motivacijom zaposlenih žena, jer je zbroj ostvarenoga i željenoga broja djece kod ispitanica $s$ tercijarnim obrazovanjem gotovo identičan onom kod žena sa sekundarnim obrazovanjem. Drugo je pitanje hoće li njihov završeni fertilitet žena biti podjednak. Skloniji smo vjerovanju da neće, barem dok se ne dogode opipljivije socioekonomske promjene, koje uključuju ne samo veću ekonomsku razvijenost nego i razvijeniju infrastrukturnu podršku zaposlenim ženama koje se odluče na rađanje kao i daleko veću jednakost među spolovima od dosadašnje, što neki demografi (vidjeti npr. McDonlad, 2000.) smatraju jednim od ključnih čimbenika koji drži fertilitet na vrlo niskoj razini, posebno u južnoeuropskim i postsocijalističkim europskim zemljama.

U radu je pokazano da je tercijarno obrazovanje povezano s vrednotama i aktivnostima koje nisu kompatibilne s imanjem djece. Sva obilježja teorije druge demografske tranzicije još nisu "zaživjela" u Hrvatskoj, no zacijelo hoće. Vjerojatnije je da je korelacija između fertiliteta i visokog obrazovanja neizravna i da djeluje preko ostalih brojnih sociopsiholoških i socioekonomskih varijabli (vidjeti detaljnije: Obradović i Čudina-Obradović, 2001.). No važno je istaknuti da su djeca i obitelj i dalje visoko vrednovani u današnjim razvijenim društvima ${ }^{6}$ - onih koji izjavljuju da ne žele djecu i obitelj ima malo (Testa, 2006.). Kao što je istaknuo van de Kaa (2001.), djeca i obitelj mogu biti dio ideje o samoispunjenju u životu, no u postmodernom društvu djeca i obitelj natječu se s drugim kompetitivnim preferencijama i prioritetima, koji nerijetko znaju prevladati. Dakle, zaključno: produženo obrazovanje (poglavito tercijarno) u Hrvatskoj više djeluje na tempo fertiliteta (vrijeme rađanja), a hoće li u istoj mjeri i na kvantum (broj djece), treba vremena da se vidi, odnosno istraživanja longitudinalnoga tipa za empirijsku potvrdu.

${ }_{1}$ Najutjecajnija grupa unutar tzv. ekonomskih teorija fertiliteta.

${ }^{2}$ Kvote su bile napravljene prema strukturi žena zaposlenih po sektorima djelatnosti.

3 Sto devedeset i jedan anketni upitnik nije vraćen anketarima ili je vraćen djelomično ispunjen. Dodatnom kontrolom isključen je i manji broj upitnika iz kojih se odgovora vidi nekonzistentnost i nelogičnost.

4 Napomenimo kako ovdje nije riječ o obrazovnoj strukturi zaposlenih žena kao u anketi nego cjelokupne ženske populacije od 20 do 39 godina. Pretpostavljamo da je obrazovna struktura zaposlenih že- 
DRUŠ. ISTRAŽ. ZAGREB GOD. 20 (2011), BR. 1 (111)

STR. $25-46$

ČIPIN, I.

OBRAZOVANJE..

\section{LITERATURA}

na znatno povoljnija od one u cjelokupnoj ženskoj populaciji. Kako možemo donijeti taj zaključak? Kao prvo, anketa je provedena 2007. kada se udio visokoobrazovanih u odnosu na 2001. sigurno povećao. Drugo, udio kućanica u navedenim dobnim grupama prema Popisu stanovništva iz 2001. dostiže razinu i do $20 \%$. Pretpostavljamo da većina njih imaju niži stupanj obrazovanja. S obzirom na to da stopa nezaposlenosti žena u Hrvatskoj nije niska, a statistika pokazuje da među njima dominiraju one nižega stupnja obrazovanja, to više možemo tvrditi da udio zaposlenih žena s tercijarnim obrazovanjem u anketi nije toliko precijenjen.

5 U analizu smo uključili samo žene koje su na pitanje planiraju li imati (još) djece odgovorile potvrdno ili niječno. One koje su odgovorile ne znam, kao i one koje su odgovorile potvrdno a nisu sigurne koliko žele, isključene su iz analize.

${ }^{6} \mathrm{O}$ tome detaljnije $\mathrm{u}$ brojnim publikacijama u sklopu Europskog istraživanja vrednota, koji se provodi i u Hrvatskoj.

Akrap, A. (2003.), Istraživanje činitelja fertiliteta u Hrvatskoj. U: A. Akrap, I. Čipin, N. Pokos, T. Ridzak i D. Živić (ur.), Činitelji demografskih kretanja u Republici Hrvatskoj (str. 85-162), Zagreb, Državni zavod za zaštitu obitelji, materinstva i mladeži.

Baizan, P., Aassve, A. i Billari, F. (2003.), Cohabitation, Marriage, and First Birth: The Interrelationship of Family Formation Events in Spain. European Journal of Population, 19 (2): 147-169.

Barber, J. S., Axinn, W. G. i Thorton, A. (2002.), The Influence of Attitudes on Family Formation Processes. U: R. Lesthaeghe (ur.), Meaning and Choice: Value Orientations and Life Course Decisions (str. 45-95), The Hague/ Brussels, NIDI/GBGS Publications.

Becker, G. (1991.), A Treatise on the Family, Cambridge, Mass.: Harvard University Press.

Billari, F. i Philipov, D. (2003.), Mutual Relationship between Education and Women's Entry into a First Union: The Case of Central and Eastern Europe. U: I. Kotowska i J. Jozwiak (ur.), Population of Central and Eastern Europe. Challenges and Opportunities (str. 201-218), Warsaw, Statistical Publishing Establishment.

Billari, F. i Philipov, D. (2004.), Education and the Transition to Motherhood: A Comparative Analysis of Western Europe. European Demographic Research Paper 3. Vienna: Vienna Institute of Demography.

Billari, F., Castiglioni, M., Castro Martín, T., Michielin, F. i Ongaro, F. (2002.), Household and Union Formation in a Mediterranean Fashion: Italy and Spain. U: E. Klijzing i M. Corijn, (ur.), Dynamics of Fertility and Partnership in Europe: Insights and Lessons from Comparative Research, vol. II (str. 17-41), Geneva/New York, United Nations.

Blossfeld, H.-P. i Huinink, J. (1991.), Human Capital Investment or Norms of Role Transition? How Women's Schooling and Career Affect the Process of Family Formation. American Journal of Sociology, 97 (1): 143-168.

Blossfeld, H.-P. (ur.) (1995.), The New Role of Women: Family Formation in Modern Societies, Boulder: Westview Press. 
DRUŠ. ISTRAŽ. ZAGREB GOD. 20 (2011), BR. 1 (111) STR. $25-46$

ČIPIN, I.: OBRAZOVANJE...
Buber, I. (2001.), The Effect of the Completion of Education on Entry into Motherhood in Austria. Working Paper Nr. 22. Vienna: Institute for Demography, Austrian Academy of Sciences.

Castles, F. G. (2003.), The World Turned Upside Down: Below Replacement Fertility, Changing Preferences and Family-Friendly Policy in 21 OECD Countries. Journal of European Social Policy, 13 (13): 209-227.

Cigno, A. i Ermisch, J. (1989.), A Microeconomic Analysis of the Timing of Births. European Economic Review, 33 (4): 737-760.

Cigno, A. (1991.), Economics of the Family, Oxford: Clarendon Press. Čudina-Obradović, M. i Obradović, J. (1999.), Želja za djecom i apstinencija od djece: odrednice, korelati i mogućnosti društvene intervencije. Revija za socijalnu politiku, 6 (3): 241-258.

DZS (2001.), Popis stanovništva, kućanstava i stanova 31. ožujka 2001., Zagreb: Državni zavod za statistiku.

Eurostat (2010.), Population and Social Conditions. Dostupno online na: http://epp.eurostat.ec.europa.eu (15. 5. 2010.)

Gerster, M., Keiding, N., Knudsen, L. B. i Strandberg-Larsen, K. (2007.), Education and Second Birth Rates in Denmark 1981-1994. Demographic Research, 17 (8): 181-210.

Gustafsson, S. (2001.), Optimal Age at Motherhood. Theoretical and Empirical Considerations on Postponement of Maternity in Europe. Journal of Population Economics, 14 (2): 225-247.

Gustafsson, S., Kenjoh, E. i Wetzelsm, C. (2002.), The Role of Education on Postponement of Maternity in Britain, Germany, the Netherlands, and Sweden. U: E. Ruspini i A. Dale (ur.), The Gender Dimension of Social Change, The Contribution of Dynamic Research to the Study of Women's Life Courses (str. 55-79), Bristol, The Policy Press.

Heiland, F., Prskawetz, A. i Sanderson, W. C. (2005.), Do the More-Educated Prefer Smaller Families? VID Working Papers 03/2005. Vienna: Vienna Institute of Demography.

Hoem, J. M. (1986.), The Impact of Education on Modern Family-Union Initiation. European Journal of Population, 2 (2): 113-133.

Huinink, J. i Kreyenfeld, M. (2004.), Family Formation in Times of Social and Economic Change: An Analysis of the 1971 East German Cohort. MPIDR Working Paper WP 2004-013, Rostock: Max Planck Institute for Demographic Research.

Inglehart, R. (1997.) Modernization and Postmodernization. Cultural, Economic, and Political Change in 43 Societies, Princeton, NJ: Princeton University Press.

Kantorová, V. (2004.), Education and Entry into Motherhood: The Czech Republic during the State Socialism and the Transition Period (1970-1997). Demographic Research, Special Collection, 3 (10): 245-274.

Kohler, H.-P., Billari, F. C. i Ortega, J. A. (2002.), Towards a Theory of Lowest-Low Fertility. Population and Development Review, 28 (4): 641-680.

Koppen, K. (2006.), Second Births in Western Germany and France. Demographic Research, 14 (14): 295-330.

Kravdal, O. (2001.), The High Fertility of College Educated Women in Norway: An Artefact of the Separate Modeling of Each Parity Transition. Demographic Research, 6 (5): 187-216. 
DRUŠ. ISTRAŽ. ZAGREB GOD. 20 (2011), BR. 1 (111)

STR. $25-46$

ČIPIN, I.:

OBRAZOVANJE...
Kreyenfeld, M. (2002.), Time-Squeeze, Partner Effect or Self-Selection? An Investigation into the Positive Effect of Women's Education on Second Birth Risks in West Germany. Demographic Research, 7 (2): $16-48$.

Lappegard, T. i Rønsen, M. (2005.), The Multifaceted Impact of Education on Entry into Motherhood. European Journal of Population, 21 (1): 31-49.

Lesthaeghe, R. (1995.), The Second Demographic Transition in Western Countries: An Interpretation. U: K. O. Mason i A.-M. Jensen (ur.), Gender and Family Change in Industrialized Countries (str. 17-62), Oxford, Clarendon Press.

Lesthaeghe, R. (2001.), Postponement and Recuperation: Recent Fertility Trends and Forecasts in Six Western European Countries. Paper presented at the IUSSP Seminar International perspectives on low fertility: Trends, theories and policies, Tokyo, 21-23 March 2001.

Lesthaeghe, R. i Surkyn, J. (1988.), Cultural Dynamics and Economic Theories of Fertility Change. Population and Development Review, 25 (2): 211-228.

Lesthaeghe, R. i Surkyn, J. (2002.), New Forms of Household Formation in Central and Eastern Europe: Are They Related to Newly Emerging Value Orientations? U: Economic Survey of Europe 2002/1 (str. 197-216), Economic Commission for Europe, United Nations, New York and Geneva.

Liefbroer, A. C. i Corijn, M. (1999.), Who, What, Where and When? Specifying the Impact of Educational Attainment and Labor Force Participation on Family Formation. European Journal of Population, 15 (1): 45-75.

Martin-Garcia, T. (2008.), A Reassessments of the Role of Women's Education in Existing Fertility Research. Genus, LXIV (1-2): 131-157.

Martin-Garcia, T. i Baizan, P. (2006.), The Impact of the Type of Education and of Educational Enrolment on First Births. European Sociological Review, 22 (3): 259-275.

McDonald, P. (2000.), Gender Equity in Theories of Fertility Transition. Population and Development Review, 26 (3): 427-439.

Nicoletti, C. i Tanturri, M. L. (2008.), Differences in Delaying Motherhood across European Countries: Empirical Evidence from the ECHP. European Journal of Population, 24 (2): 157-183.

Obradović, J. i Čudina-Obradović, M. (2001.), Korelati i odrednice broja djece u obitelji. Društvena istraživanja, 10 (4-5): 655-683.

Olah, L. S. (2003.), Gendering Fertility: Second Births in Sweden and Hungary. Population Research and Policy Review, 22 (2): 171-200.

Oppenheimer, K. (1994.), Women's Rising Employment and the Future of the Family in Industrial Societies. Population and Development Review, 20 (2): 293-342.

Pokos, N. (2005.), Glavne značajke obrazovne strukture stanovništva Hrvatske. U: D. Živić, N. Pokos i A. Mišetić (ur.), Stanovništvo Hrvatske - dosadašnji razvoj i perspektive (str. 145-160), Institut društvenih znanosti Ivo Pilar, Zagreb. 
DRUŠ. ISTRAŽ. ZAGREB GOD. 20 (2011), BR. $1(111)$ STR. $25-46$

ČIPIN, I. OBRAZOVANJE..
Róbert, P. i Bukodi, E. (2005.), The Effects of the Globalization Process on the Transition to Adulthood in Hungary. U: H.-P. Blossfeld, E. Klijzing, M. Mills i K. Kurz (ur.), Globalization, Uncertainty and Youth in Society - The Losers in a Globalizing World (str. 177-213), Routledge, London.

Sobotka, T. (2004.), Is the Lowest-Low Fertility Explained by the Postponement of Childbearing? Population and Development Review, 30 (2): 195-220.

Testa, M. R. (2006.), Childbearing Preferences and Family Issues in Europe. Special Eurobarometer 253/Wave 65.1 - TNS Opinion \& Social, European Commission.

Van de Kaa, D. J. (1987.), Europe's Second Demographic Transition. Population Bulletin, 42 (1): 1-59.

Van de Kaa, D. (2001.), Postmodern Fertility Preferences: From Changing Value Orientation to New Behavior. Population and Development Review, A Supplement, 27: 290-331.

Wertheimer-Baletić, A. (1971.), Stanovništvo SR Hrvatske - Studije, Zagreb: Školska knjiga.

Wertheimer-Baletić, A. (2003.), Determinante reprodukcije stanouništva Hrvatske u drugoj polovici 20. stoljeća, RAD, knjiga 487, Razred za društvene znanosti, HAZU, Zagreb, str. 377-401.

\section{Education and Fertility of Employed Women in Croatia}

Ivan ČIPIN

Faculty of Economics and Business, Zagreb

This paper investigates to what extent women's educational attainment is related to their demographic behavior, especially the age of first birth and the ultimate number of children. The purpose of this paper is to investigate whether the difference in the age of first birth among women with a different educational attainment exists and how significant it is. Additionally, we investigate the impact of different educational attainment of women on the fertility quantum. Multinomial logistic regression and other statistical techniques are applied to the data from the survey conducted in 2007 on the proportional quota sample of 1309 employed women in Croatia aged 20-39. The results show that there are differences in women's fertility according to their educational attainment, and educational attainment has a significant role in determining the timing of fertility. When applying pro-natalistic policy measures, one should bear in mind that the highest difference between the actual and desired number of children is found among highly educated women.

Keywords: fertility, age of first birth, women's educational attainment, employed women 
DRUŠ. ISTRAŽ. ZAGREB GOD. 20 (2011) BR. 1 (111)

STR. $25-46$

ČIPIN, I.:

OBRAZOVANJE...

\section{Bildungsstand und Kinderwunsch bei berufstätigen Fraven in Kroatien}

\author{
Ivan ČIPIN
}

Wirtschaftswissenschaftliche Fakultät, Zagreb

In dieser Arbeit wird untersucht, welche Auswirkungen der Bildungsstand der Frau auf demografisch relevante Verhaltensweisen hat, insbesondere darauf, in welchem Alter sie das erste Kind zur Welt bringt, sowie auf die Gesamtkinderzahl. Der Autor möchte herausfinden, ob es hinsichtlich des ersten Kindes einen Unterschied zwischen Frauen mit und ohne Ausbildung gibt und wie bedeutend dieser Unterschied ist. Des Weiteren wird hinterfragt, inwiefern ein höherer Bildungsstand die Geburtenzahl beeinflusst. Dabei werden die Instrumente der multinomen legistischen Regression sowie andere multivariate Techniken auf die Ergebnisse einer Umfrage angewandt, an der 2007 insgesamt 1309 berufstätige Fraven im Alter von 20 bis 39 Jahren aus Kroatien teilnahmen. Es zeigte sich, dass der genannte Unterschied tatsächlich existiert sowohl bezüglich des Kinderwunsches allgemein als auch im Hinblick auf das Timing der Familiengründung bzw. -erweiterung. Bei der Gestaltung politischer Maßnahmen zur Steigerung der Geburtenrate sollte berücksichtigt werden, dass die größten Unterschiede zwischen der gewünschten und der realisierten Kinderzahl bei Fraven mit hohem Bildungsstand anzutreffen sind.

Schlüsselbegriffe: Geburtenrate, Erstgeburtsalter, Bildungsstand von Fraven, berufstätige Fraven 